\title{
Possible Effects of Climate Warming on Selected Populations of Polar Bears (Ursus maritimus) in the Canadian Arctic
}

\author{
IAN STIRLING $^{1}$ and CLAIRE L. PARKINSON ${ }^{2}$
}

\author{
(Received 10 November 2005; accepted in revised form 25 January 2006)
}

\begin{abstract}
Polar bears depend on sea ice for survival. Climate warming in the Arctic has caused significant declines in total cover and thickness of sea ice in the polar basin and progressively earlier breakup in some areas. Inuit hunters in the areas of four polar bear populations in the eastern Canadian Arctic (including Western Hudson Bay) have reported seeing more bears near settlements during the open-water period in recent years. In a fifth ecologically similar population, no changes have yet been reported by Inuit hunters. These observations, interpreted as evidence of increasing population size, have resulted in increases in hunting quotas. However, long-term data on the population size and body condition of polar bears in Western Hudson Bay, as well as population and harvest data from Baffin Bay, make it clear that those two populations at least are more likely to be declining, not increasing. While the ecological details vary in the regions occupied by the five different populations discussed in this paper, analysis of passive-microwave satellite imagery beginning in the late 1970s indicates that the sea ice is breaking up at progressively earlier dates, so that bears must fast for longer periods during the open-water season. Thus, at least part of the explanation for the appearance of more bears near coastal communities and hunting camps is likely that they are searching for alternative food sources in years when their stored body fat depots may be depleted before freeze-up, when they can return to the sea ice to hunt seals again. We hypothesize that, if the climate continues to warm as projected by the Intergovernmental Panel on Climate Change (IPCC), then polar bears in all five populations discussed in this paper will be increasingly food-stressed, and their numbers are likely to decline eventually, probably significantly so. As these populations decline, problem interactions between bears and humans will likely continue, and possibly increase, as the bears seek alternative food sources. Taken together, the data reported in this paper suggest that a precautionary approach be taken to the harvesting of polar bears and that the potential effects of climate warming be incorporated into planning for the management and conservation of this species throughout the Arctic.
\end{abstract}

Key words: climate warming, polar bear, Ursus maritimus, sea ice, Arctic

RÉSUMÉ. La survie des ours polaires dépend de la glace. Dans l'Arctique, le réchauffement climatique fait diminuer considérablement l'étendue et l'épaisseur de la glace de mer du bassin polaire et engendre une débâcle qui se produit progressivement plus tôt dans certaines régions. Ces dernières années, les chasseurs inuits des régions habitées par quatre populations d' ours polaire dans l'est de l'Arctique canadien (ce qui comprend l'ouest de la baie d'Hudson) ont signalé avoir aperçu une plus grande quantité d'ours près des agglomérations pendant la période des eaux libres. Au sein d'une cinquième population écologiquement semblable, les chasseurs inuits n'ont signalé aucun changement. Ces observations, interprétées comme des preuves de l'accroissement des populations, ont entraîné l'augmentation des quotas de chasse. Cependant, selon les données à long terme concernant l'effectif des populations et la condition physique des ours polaires de l'ouest de la baie d'Hudson, de même que les données concernant les populations et les captures de la baie de Baffin, il est clair que ces deux populations sont, à tout le moins, plus susceptibles de décliner et non pas d'augmenter. Bien que les conditions écologiques des régions visées par les cinq populations dont il est question dans cet article diffèrent, l' analyse de l'imagerie satellite à hyperfréquences passives de la fin des années 1970 laisse croire que la débâcle de la glace de mer se produit progressivement plus tôt, ce qui signifie que les ours doivent jeûner pendant plus longtemps au cours de la période des eaux libres. Par conséquent, la présence d'un plus grand nombre d'ours près des agglomérations de la côte et des camps de chasse s'explique donc en partie par le fait que les ours seraient à la recherche de sources de nourriture de rechange au cours des années où leurs dépôts de graisse s'épuisent avant la prise de la glace, moment auquel ils peuvent regagner la glace de mer pour recommencer à chasser les phoques. Notre hypothèse est la suivante : si le climat continue de se réchauffer, tel que projeté par le Groupe d'experts intergouvernemental sur l'évolution du climat (GIEC), les ours polaires des cinq populations dont il est question dans ce document ressentiront de plus en plus les effets de la privation d'aliments, ce qui engendrera leur déclin, probablement de manière considérable. Au fur et à mesure que ces populations chuteront, les interactions entre les ours et les êtres humains continueront vraisemblablement d'être problématiques, au point même de s'intensifier car les ours seront à la recherche de nouvelles sources de nourriture. Prises ensemble, les données précisées dans ce document laissent supposer qu'il y a lieu d'adopter des mesures de précaution en matière de capture des ours polaires et que les effets éventuels du réchauffement du climat devraient être intégrés à la planification de la gestion et de la conservation de cette espèce à la grandeur de l'Arctique.

\footnotetext{
${ }^{1}$ Canadian Wildlife Service, 5320122 Street, Edmonton, Alberta T6H 3S5, Canada; ian.stirling@ec.gc.ca

${ }^{2}$ NASA Goddard Space Flight Center, Cryospheric Sciences Branch/Code 614.1, Greenbelt, Maryland 20771, U.S.A.

(C) The Arctic Institute of North America
} 
Mots clés : réchauffement climatique, ours polaire, Ursus maritimus, glace de mer, Arctique

Traduit pour la revue Arctic par Nicole Giguère.

\section{INTRODUCTION}

Polar bears (Ursus maritimus) are distributed throughout the ice-covered waters of the circumpolar Arctic in 20 relatively discrete subpopulations (Lunn et al., 2002a). Initially, and until recently, scientists considered harvesting to be the principal threat to polar bear populations because of their low reproductive rate. In response to unregulated harvesting throughout most of the polar bear's circumpolar range in the $1960 \mathrm{~s}$, the five nations with polar bears in their jurisdictions negotiated the Agreement on the Conservation of Polar Bears, signed in Oslo, Norway in 1973 (Stirling, 1988: Appendix I; Prestrud and Stirling, 1994). Article II of the Agreement states: "Each Contracting Party shall take appropriate action to protect the ecosystems of which polar bears are a part, with special attention to habitat components such as denning and feeding sites and migration patterns, and shall manage polar bear populations in accordance with sound conservation practices based on the best available scientific data." In Canada, "sound conservation practices" has been interpreted to include sustainable hunting by aboriginal people, regulated through an annual quota, usually estimated from the results of a scientifically conducted (mark-recapture) population assessment. In Nunavut and the Northwest Territories, a high priority is also placed on incorporating Inuit hunters' "traditional knowledge" of wildlife, as well as scientific knowledge, into decision making about wildlife management practices (GNWT, 2005).

In February 2005, the Department of Environment of the Government of Nunavut, Canada, announced an overall increase in polar bear quotas in the Territory of $28.5 \%$, varying from $0 \%$ to $64 \%$ between different subpopulations. For the majority of populations in which the quotas were increased, the estimates of population size, and the sustainable quotas from them, were determined on the basis of scientific studies (mark-recapture, survival rates, and reproductive rates). However, in four populations-Western Hudson Bay, Foxe Basin, Baffin Bay, and Davis Strait (Fig. 1)-Inuit traditional knowledge was the primary information source that influenced the quota increase. More specifically, Inuit hunters in these four populations had reported seeing more bears in recent years around settlements, hunting camps, and sometimes locations where they had not (or only rarely) been seen before, resulting in an increase in threats to human life and damage to property. Most of these bears were seen along or near the coast during the open-water season in fall. In those regions, the increased number of bears seen was interpreted as evidence that the populations were growing, and this conclusion greatly influenced the decision to increase the annual quotas (Table 1). The figures on previous and current harvest quotas for Canada and Greenland listed in Table 1 are summarized from Derocher et al. (1998), Lunn et al. (2002a), and Aars et al. (in press).

Unfortunately, few hunters or other residents in Nunavut have documented the actual numbers of bears they have seen over time, the dates or locations of their sightings, or the approximate age and sex composition of bears perceived as problems. Nor do we have other information that could be evaluated independently, such as the physical condition or fatness of problem bears killed or the number of trips to the same areas during which no or few bears were seen. Regardless, Inuit observations of wildlife are generally regarded as accurate (e.g., Nakashima, 1993), so the conclusion that hunters have been seeing more bears in recent years, at times and places where they used to see them less frequently, can be considered reliable. However, to date, no study has attempted to evaluate whether explanations other than an increase in population size could account for the increase in polar bear sightings. Possible additional factors include changes in the distribution or abundance of prey species and sea ice, both of which the bears depend on for their existence.

Although quantitative data exist on the distribution, abundance, and life history of prey species in some areas occupied by these polar bear populations (e.g., Lunn et al., 1997; Ferguson et al., 2005; Stirling, 2005), they are generally inadequate for more than speculation about their possible relevance to trends in polar bear populations. A possible exception is the documentation of increases in numbers of harp (Pagophilus groenlandicus) and hooded (Cystophora cristata) seals and the species composition of polar bear diets in Davis Strait (Healey and Stenson, 2000; Anonymous, 2005; Iverson et al., 2006).

In contrast, over the last 20 years or so, there has been considerable documentation of significant reductions in sea-ice cover in several parts of the Arctic, thinning of multiyear ice in the polar basin and seasonal ice in Hudson Bay, and changes in the dates of breakup and freeze-up of the sea ice, likely as a consequence of climate warming (e.g., Parkinson and Cavalieri, 1989; Parkinson et al., 1999; Rothrock et al., 1999; Comiso and Parkinson, 2004; Gough et al., 2004a, b; Gagnon and Gough, 2005). Because polar bear populations depend on sea ice, changes in its distribution and abundance could have significant impact on their health (Stirling and Derocher, 1993; Derocher et al., 2004). Furthermore, in Western Hudson Bay at least, recent studies have confirmed that the ice is melting earlier, apparently in response to climate warming, and that both the condition of bears and their population size are declining (Stirling et al., 1999; Gagnon and Gough, 2005; Regehr et al., 2005; I. Stirling and N.J. Lunn, unpubl. data). 


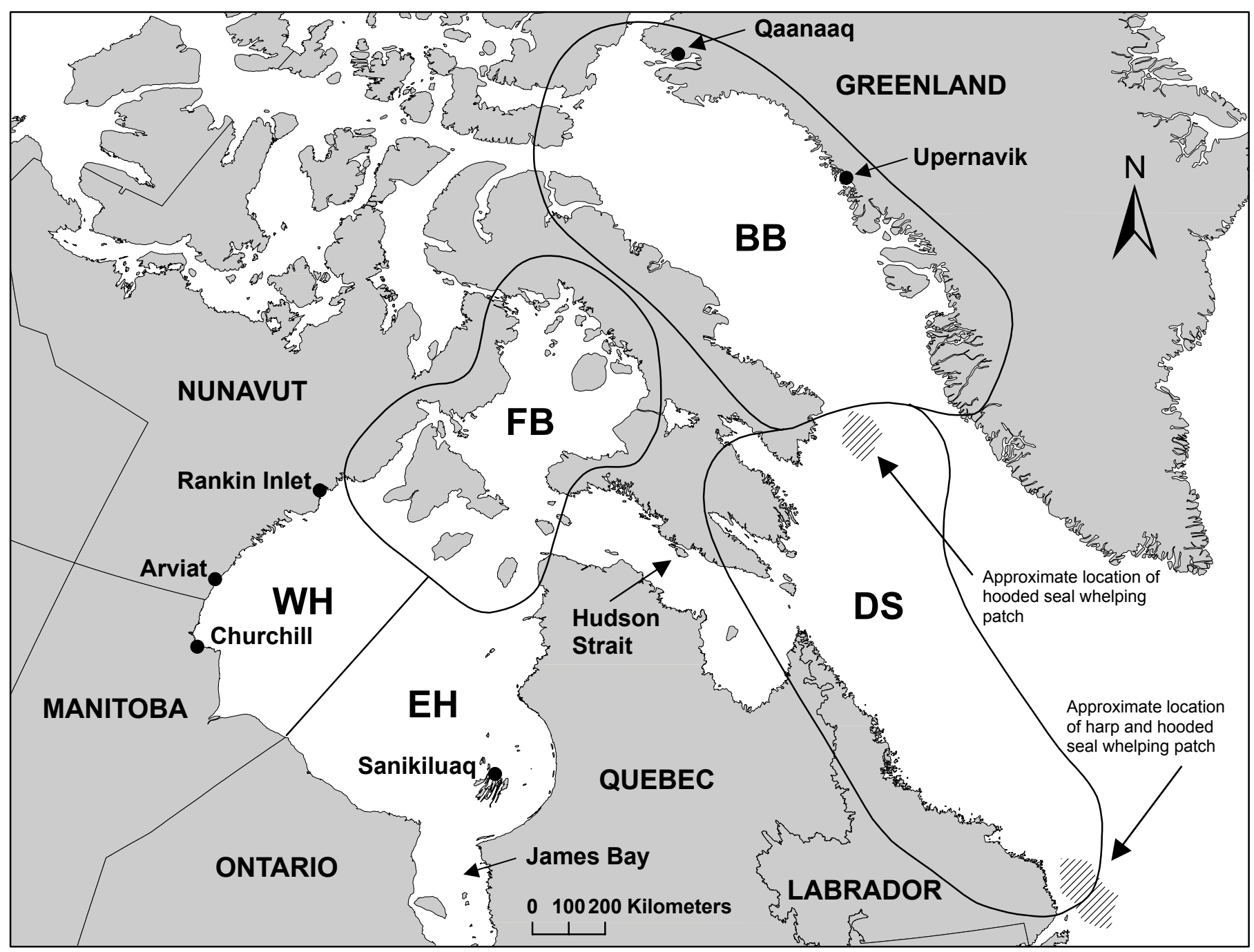

FIG. 1. Map of the study area showing delineation of area of each polar bear population discussed (WH - Western Hudson Bay; EH - Eastern Hudson Bay; FB - Foxe Basin; BB - Baffin Bay; DS - Davis Strait).

Because of the increase in sightings of polar bears on land near settlements and outpost camps in recent years, the Nunavut Department of Environment agreed with the hunters' conclusion that the populations have been increasing in Western Hudson Bay, Foxe Basin, Baffin Bay, and Davis Strait (Fig. 1). These regions have in common that every summer, the sea ice melts completely, or very nearly so, so that all bears in these populations must spend several months on shore surviving on their stored fat reserves and whatever limited and unpredictable food sources they might find on land. In this paper, we evaluate patterns of sea-ice breakup and freeze-up in each of these areas to test the hypothesis that sightings of more polar bears in these populations are due in part to changes in sea ice, possibly resulting from climate warming, and do not necessarily indicate population increases. Although no increases in numbers of polar bears have been reported from Eastern Hudson Bay (including James Bay, Fig. 1), we have included it in our study because polar bears in that area, like bears of the other four populations studied, must fast on their stored fat reserves for several months during the open-water period in summer and fall.

\section{MATERIALS AND METHODS}

\section{Study Area}

The five regions for which we analyze patterns of ice breakup are based on the accepted boundaries of the polar bear management zones used by the respective government agencies in Canada and Greenland (Lunn et al., 2002b; Fig. 1). These boundaries were delineated using studies of movements of tagged bears of all age and sex classes, the annual movements of adult females wearing satellite radio collars, and genetic studies (e.g., Paetkau et al., 1999; Taylor et al., 2001; Stirling et al., 2004). The boundaries we use for Western Hudson Bay, Eastern Hudson Bay, and Baffin Bay are based on Lunn et al. (2002b), whereas those we use for Foxe Basin and Davis 
TABLE 1. Changes proposed by the Nunavut Department of Environment to polar bear harvest quotas for five populations of polar bears harvested entirely or partially by Nunavut hunters.

\begin{tabular}{|c|c|c|c|c|}
\hline Population & $\begin{array}{l}\text { Estimated population size } \\
\text { on which quota is based }\end{array}$ & $\begin{array}{l}\text { Quotas that applied through } \\
\text { the 2004-05 hunting season } \\
\text { (Nunavut portion in parentheses) }\end{array}$ & $\begin{array}{l}\text { Proposed increases in Nunavut } \\
\text { quotas only (as of Feb. 2004) }\end{array}$ & $\begin{array}{c}\text { Proposed increases to Nunavut } \\
\text { portions of quotas (as of Jan. 2005) } \\
\text { (\% increase in parentheses) }\end{array}$ \\
\hline Baffin Bay & 2074 & $(64)^{1}$ & 0 & $41(64 \%)=105$ total $^{2}$ \\
\hline Foxe Basin & 2119 & (97) & 9 & $9(9 \%)=106$ total \\
\hline Davis Strait & 1400 & $40(34)^{3}$ & 12 & $12(35 \%)=46$ \\
\hline Western Hudson Bay & 1200 & $55(47)^{4}$ & 9 & $9(19 \%)=56$ \\
\hline Eastern Hudson Bay & 1000 & $55(25)^{5}$ & 0 & 0 \\
\hline
\end{tabular}

${ }^{1}$ No quota observed by Greenland.

${ }^{2}$ Quota of 100 for West Greenland adopted January 2005.

${ }^{3}$ No quota observed by Greenland or Quebec; quota of 6 in Labrador.

${ }^{4}$ Maximum of 8 bear quota retained by Manitoba for control of problem bears.

${ }^{5}$ Quota of 30 in Ontario Indian villages.

Strait are modified (Fig. 1). Although it is known from movements of tagged and radio-collared bears that some individuals move back and forth through Hudson Strait (Stirling and Kiliaan, 1980; Taylor et al., 2001), the majority appear to remain either in Foxe Basin or in Davis Strait, so we did not include Hudson Strait in our ice analysis of either zone. For Davis Strait, our eastern boundary extends only as far as the approximate maximum limit of ice in winter (e.g., Gloersen et al., 1992) in order to exclude the large area that remains unfrozen in the zone defined by Lunn et al. (2002b). Although occasional polar bears are recorded along the coast of Newfoundland, most of the radiocollared individuals did not go south of the southern tip of Labrador (Taylor et al., 2001; I. Stirling, unpubl. data), so we used that point as the limit for the Davis Strait region.

\section{Satellite Sea-Ice Data}

Satellites have collected multichannel passive-microwave data on the Arctic sea-ice cover since late 1978. These data allow the frequent monitoring of the ice cover to a resolution of approximately $25 \mathrm{~km}$. The data are collected day and night, in all seasons of the year, and under all weather conditions. They take advantage of the difference between the microwave emissions by ice and by liquid water and the fact that radiation at many microwave wavelengths can pass readily through most clouds (e.g., Parkinson, 2000b).

We used two satellite passive-microwave data sets, one from NASA's Nimbus 7 Scanning Multichannel Microwave Radiometer (SMMR) and the other from the Defense Meteorological Satellite Program (DMSP) Special Sensor Microwave Imager (SSMI). The Nimbus 7 SMMR was launched in October 1978 and collected data through midAugust 1987, mostly every other day. The first SSMI was launched on the DMSP F8 satellite in June 1987, and subsequent SSMIs have been launched on later DMSP satellites, together providing a daily record of the sea-ice cover for almost all of the period since June 1987. We used the SSMI record through the end of 2004, the last full year prior to this study.
The SMMR and SSMI radiative data are converted to sea-ice concentrations (percent areal coverages of sea ice) through a multichannel algorithm based on polarization and gradient ratios. Details on the algorithm were given by Gloersen et al. (1992), and details on matching the SMMR and SSMI records were given by Cavalieri et al. (1999). The ice concentrations, archived at and available from the U.S. National Snow and Ice Data Center in Boulder, Colorado, are used to determine both regional and hemispheric ice extents and ice areas. Ice extents are calculated by summing the areas of all pixels (grid elements, approximately $25 \mathrm{~km} \times 25 \mathrm{~km}$ ) with at least $15 \%$ ice concentration in the region of interest; and ice areas are calculated by summing the products of the area and ice concentration of all pixels with at least $15 \%$ ice concentration. Results have shown considerable interannual variability in the Arctic sea-ice cover, especially when examined regionally, but they have also shown a strong signal toward lessened seaice extents and areas since late 1978 (Parkinson and Cavalieri, 1989; Johannessen et al., 1995, 2004; Maslanik et al., 1996; Bjørgo et al., 1997; Parkinson et al., 1999).

For this paper, we calculated ice areas for the polar bear regions identified in Figure 1 and divided these ice areas by the area of the respective region, to obtain daily percent ice coverages. For the SMMR years, in which data were generally collected only every other day, we performed temporal interpolation, linearly from the preceding and following dates, to provide values for the days without data. Similarly, we filled in missing data throughout the data set by interpolation, to produce a complete daily data set. From the completed data set, we determined the date in each year when the ice cover fell to below 50\%, then calculated the trend on that date over the course of the 1979-2004 record. The trend is calculated as the slope $b$ of the line of linear least squares fit through the data points and is accompanied by the standard error $\sigma$ of the slope. Statistical significance is estimated through use of the normal error integral, with a $p$ value indicating the probability of obtaining a $b / \sigma$ quotient as large in magnitude as the observed value in the event of a mean slope of 0 . The 
difference $1.0-p$ provides an estimated confidence level for the hypothesis that $b$ differs from 0 . We defined breakup as the point when the decline in the total cover of the melting sea ice reached 50\%, following Etkin (1991), Stirling et al. (1999), and Gagnon and Gough (2005). Furthermore, Stirling et al. (1999: Fig. 4) documented a statistically significant relationship between the time when the total sea-ice cover declined to 50\% and the time when the bears subsequently came ashore in Western Hudson Bay (24.6 \pm 0.87 days later, range $=21-28$ days $)$. This relationship also indicates that the $50 \%$ value is biologically meaningful in the context of our analyses.

\section{Polar Bears}

Each fall in Western Hudson Bay, we measured the straight-line body length and axillary girth of about 100 300 immobilized polar bears in order to estimate their weights and overall body condition (Stirling et al., 1989, 1999). To control for variation between years in the dates on which individual bears were captured, we scaled weights to a constant capture date of 21 September by adding (or subtracting) $0.85 \mathrm{~kg}$ to (or from) the weights of all bears for each day by which their capture preceded (or followed) that date (Derocher and Stirling, 1992). The results of analyses of condition data from adult males and adult females accompanied by dependent young were given elsewhere (Stirling et al., 1999; I. Stirling and N.J. Lunn, unpubl. data). In this paper, we present the mean estimated mass of lone (and thus possibly pregnant) adult female polar bears in Western Hudson Bay from 1980 through 2004.

Recording of observations of problem bears varies widely among areas. However, at Churchill, Manitoba (Fig. 1), conservation officers record all problem bears reported in the area throughout the year, although most incidents occur during the open-water season. Similar records are not kept in Nunavut. Bears killed there because they threatened human life or property are usually recorded as "problem kills," but if a regular harvest quota tag is used for the hide, the bear may or may not have been recorded as having been a problem.

We used a Pearson product-moment correlation to test for statistical significance in the relationship between the number of problem bears handled in Churchill versus the date of breakup and a linear regression to test for significance between weights of lone females in fall versus year.

\section{RESULTS AND DISCUSSION}

\section{Western Hudson Bay}

Figure 2a presents a time series of the daily percent ice coverages in Western Hudson Bay, from 1 November 1978 through 31 December 2004, as determined from the satellite SMMR and SSMI data. Figure $2 b$ presents a plot of the
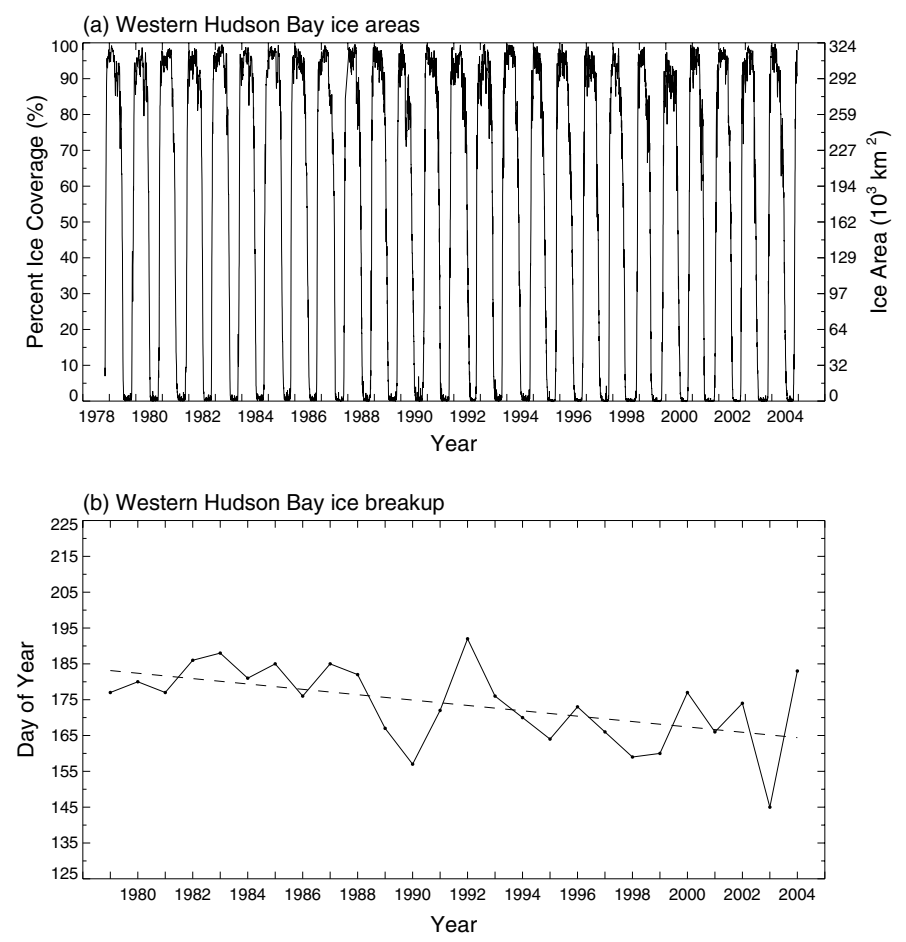

FIG. 2. Western Hudson Bay: (a) Time series of the daily percent ice coverages and ice areas from 1 November 1978 through 31 December 2004, as determined from the satellite SMMR and SSMI data, and (b) the Julian dates by which the percent ice coverage decreased to $50 \%$ or less, following the winter maximum, for the years 1979-2004 (dashed line indicates fit of linear regression).

Julian dates by which the percent ice coverage decreased to $50 \%$ or less, following the winter maximum, for the years 1979-2004.

Although these data show some interannual variability, there is a clear overall trend toward progressively earlier sea-ice breakup. A linear least-squares fit through the data points of Figure $2 b$ yields a slope of $-0.75 \pm 0.25$ days/year, which is statistically significant at a confidence level exceeding $99 \%$ ( $p=0.003)$. On average, breakup has been occurring about $7-8$ days earlier per decade. The earliest breakup came in the penultimate year of our data record, 2003 , although it was followed by a late breakup in the last year of the record, 2004. The second earliest breakup came in the middle of the record, in 1990, and was followed two years later by the latest breakup, in 1992 (the cold year that followed the eruption of Mt. Pinatubo in 1991; e.g., Soden et al., 2002).

Similar trends showing progressively earlier breakup of the sea ice in Western Hudson Bay and the southern portion of Eastern Hudson Bay were documented by Stirling et al. (1999, 2004), Gough et al. (2004a), and Gagnon and Gough (2005). Gagnon and Gough (2005) also reported significant autocorrelation in areas of Hudson Bay for freeze-up and break-up dates.

Skinner et al. (1998) reported that the temperature at Churchill and over the adjacent sea ice during April through June had warmed at $0.3-0.5^{\circ} \mathrm{C}$ per decade from 1950 to 1990 , and Gagnon and Gough (2005) reported that the annual temperature at Churchill had increased $0.5^{\circ} \mathrm{C}$ per decade over 


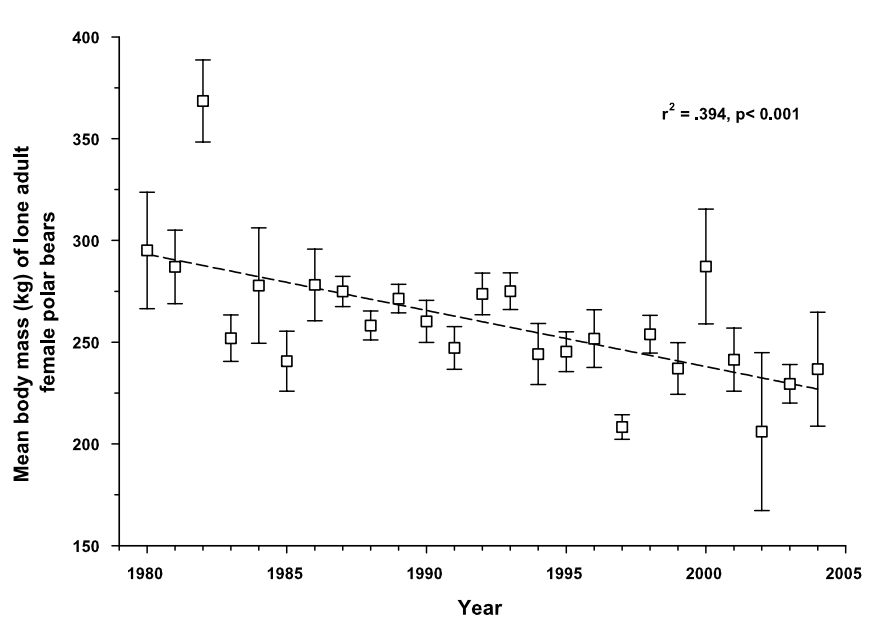

FIG. 3. Mean estimated mass of lone (and thus possibly pregnant) adult female polar bears in Western Hudson Bay from 1980 through 2004 (dashed line indicates fit of linear regression).

the period 1971-2001. Gough et al. (2004b) further found sea-ice thickness in some areas of Hudson Bay to be dependent on pre-conditioning of the waters in the previous summer season. Thus, progressively earlier breakup in Western Hudson Bay (Fig. 2b) is significantly correlated with, and most likely caused by, climate warming.

In Western Hudson Bay (Fig. 1), all bears in the population must fast for at least four months during the ice-free season. Pregnant females, however, must fast for eight months because they give birth to cubs in maternity dens at about the time the rest of the population can return to the ice to hunt seals again (Ramsay and Stirling, 1988). Gagnon and Gough (2005) and Stirling et al. (2004) reported that the sea ice is breaking up about three weeks earlier than it did 30 years ago, an estimate consistent with the trend line in Figure 2b. Consequently, over those decades, the entire polar bear population of Western Hudson Bay has been forced to come ashore progressively earlier to begin fasting and also to fast for a longer period (Stirling et al., 1999; N. Lunn and I. Stirling, unpubl. data). There is a statistically significant relationship between the date of breakup and the condition of the bears when they come ashore: i.e., the earlier the breakup, the poorer the condition of the bears, and conversely (Stirling et al., 1999). Most polar bears can probably handle a single short ice season without a major problem. However, as the number of consecutive short ice seasons increases, the cumulative stress on the polar bears is bound to increase as well. Prior to 1998, the population had apparently remained stable (Stirling et al., 1999), indicating that the annual harvest of approximately 50 bears (Lunn et al., 1998) had been sustainable. However, as bears progressively lost condition, the survival of cubs, subadults, and bears 20 years of age and older declined and, when added to the loss of bears through harvesting, probably initiated a decline in the total size of the Western Hudson Bay polar bear population. Once the population began to decline, the harvest was no longer sustainable; however, it remained unchanged (Lunn et al.,
$2002 \mathrm{~b}$, in press) so that its additive contribution to the reduction in total population size probably accelerated between 1988 and 2004. In those years, the total population declined from $1194(95 \% \mathrm{CI}=1020,1368)$ in 1987 to $935(95 \%$ CI $=794,1076)$ in 2004 , a reduction of about 22\% (Regehr et al., 2005; I. Stirling and N.J. Lunn, unpubl. data).

Figure 3 shows the decline in mean estimated mass of lone (and thus possibly pregnant) adult female polar bears in Western Hudson Bay from 1980 through 2004. Their average weight declined by about $65 \mathrm{~kg}$ (from 295 to about $230 \mathrm{~kg})$, a change that is statistically significant $\left(\mathrm{F}_{1,23}=\right.$ $\left.15.1, \mathrm{r}^{2}=.394, p<0.001\right)$. Atkinson and Ramsay (1995) and Derocher and Stirling (1996) demonstrated a strong relationship between the body weight of an adult female in the fall and the subsequent survival of her young, i.e., fatter females produced larger cubs that survived better. Further, Derocher et al. (1992) reported that no females weighing less than $189 \mathrm{~kg}$ in the fall were recorded with cubs the following spring, suggesting that $189 \mathrm{~kg}$ approximates a minimum weight below which the bears can no longer successfully reproduce. Given that the current average weight of lone adult females in the fall is about $230 \mathrm{~kg}$, and if their mean weight continues to decline at a similar rate, most will stop producing cubs within the next 20 to 30 years if the climate continues to warm as currently projected by the IPCC. Further, since the average weights of the females that do produce cubs will also decline if the trends in temperature and ice breakup documented to date continue as predicted, the weights of cubs will also decline, as will their chances for survival.

The number of problem bears being handled by Conservation Officers at Churchill in Western Hudson Bay has increased dramatically over the past decade (Fig. 4a), and there is a statistically significant relationship between the date of breakup of the sea ice and the number of bears handled (i.e., the earlier the ice breaks up, the more problem bears there are, and conversely) (Fig. 4b). Over a similar period, residents of the Nunavut coast of Western Hudson Bay, from Arviat to Rankin Inlet, have also reported seeing many more polar bears in the ice-free months, especially in recent years, though there has been no documentation of numbers. Since the progressively earlier breakup is also significantly correlated with a decline in the bears' physical condition (Stirling et al., 1999), it seems clear that many bears, especially subadults, are exhausting their stored body fat before freeze-up when they can return to the ice and hunt seals. Thus, the more likely reason for increasing numbers of polar bears coming into coastal settlements in Western Hudson Bay is that they are hungry, and not that their population is increasing. This conclusion is supported by an extensive analysis of the population data collected continuously since the 1980s, which demonstrated that the polar bear population declined by $22 \%$ from about 1200 in 1989 to about 950 in 2004 (Regehr et al., 2005; I. Stirling and N.J. Lunn, unpubl. data). 

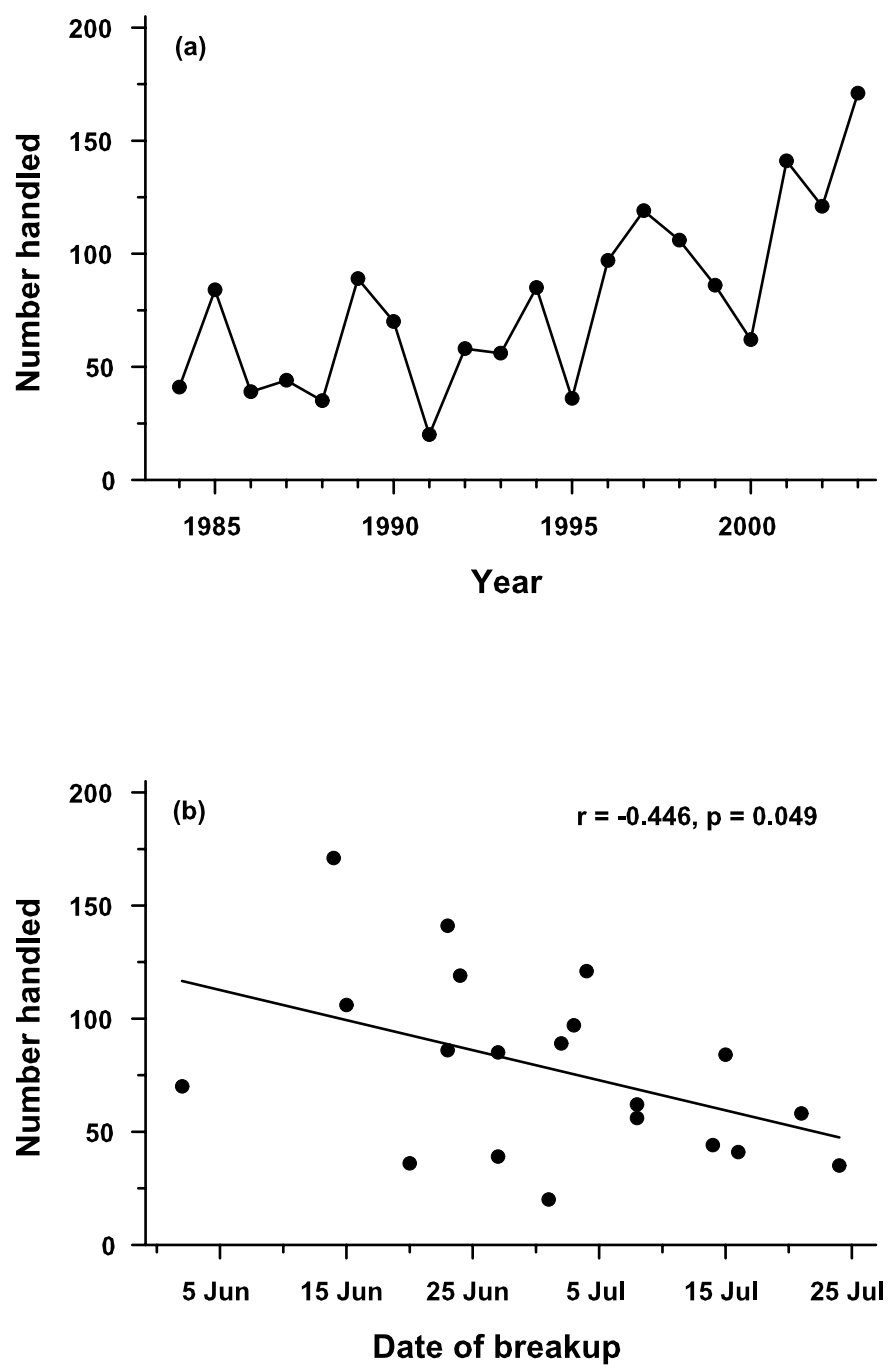

FIG. 4. (a) The number of problem bears handled by the Conservation Officers in Churchill in Western Hudson Bay from 1984 through 2003, and (b) the relationship between the date of sea-ice breakup and the number of problem bears handled (solid line indicates fit of Pearson product-moment correlation).

Although the decline in the bears' condition in recent decades is likely related to progressively earlier breakup (which shortens the time available to them to hunt and store fat to fast through the open-water season), other factors may be involved as well. For example, Ferguson et al. (2005) and Stirling (2005) documented a reduction in recruitment of ringed seals, reduced survival of their young, and a slight reduction in the pregnancy rates of adult females. The reasons for these changes are unclear, but it is possible that some factor related to the warming climate and loss of sea ice is having additional but unknown ecological effects on the marine ecosystem of Hudson Bay and hence on the distribution, survival, or availability of ringed seals. Gaston et al. (2003) documented a large-scale change in the diet of thick-billed murres (Uria lomvia) in northern Hudson Bay as the area of open water adjacent to the breeding colony increased greatly in size during the period when chicks were being fed. The loss of ice appeared to be caused by the warming climate, and the change in diet associated with increased open water suggests the possibility of a major shift in ecosystem dynamics. Lastly, warmer springs may cause ringed seal birth lairs to collapse prematurely or bring unseasonable rain that causes the birth lair roofs to collapse or wash away (e.g., Kelly, 2001; Stirling and Smith, 2004), leaving the young seals vulnerable to high levels of predation and exposure to the elements. Cumulatively, these events may be having a negative effect on the ringed seal population in Western Hudson Bay on which polar bears principally depend.

\section{Foxe Basin}

Figure 5a presents a time series of percent ice coverage in Foxe Basin from 1 November 1978 through 31 December 2004, as determined from the satellite SMMR and SSMI data. Figure $5 \mathrm{~b}$ presents a plot of the Julian dates by which the percent ice coverage decreased to $50 \%$ or less, following the winter maximum, for the years 1979-2004. As in Western Hudson Bay, there is a clear overall trend toward earlier ice breakup, with a linear least-squares fit rate of $-0.58 \pm 0.19$ days/year, which was statistically significant at a confidence level exceeding 99\% ( $p=$ 0.002). That is, ice coverage in Foxe Basin has been reducing to $50 \%$ about six days earlier each decade. As in Western Hudson Bay, the earliest ice breakup was in 2003.

Most previous examinations of trends in ice amounts or breakup times for Foxe Basin have considered that area together with Hudson Bay, and sometimes Hudson Strait, as a single unit (e.g., Parkinson et al., 1999). However, in examining the length of the sea-ice season, much greater spatial detail is possible. Trends in the length of the sea-ice season in Foxe Basin were determined to be slightly positive over the 1979-86 period of the SMMR satellite record (Parkinson, 1992) but slightly negative (a shorter ice season, longer open-water season) when the record was extended, through the addition of SSMI data, to cover the period 1979-96 (Parkinson, 2000b). Heide-Jørgensen and Laidre (2004) examined several relatively small areas known to have open water in March and thus to be important to marine mammals. They found that between 1979 and 2001, there was a steady trend toward larger openwater areas, which is consistent with our results for the overall area.

The size of the Foxe Basin polar bear population in 1996 was estimated to be about 2100 (Table 1). On the basis of local reports of seeing more polar bears in recent years, it was assumed the population had increased, so the "target" population was increased to 2300 and the quota was raised from 97 to 106. No other studies that might support or negate that conclusion have been conducted since 1996 . Other factors, such as climate warming in particular, might also be contributing to the sighting of more bears around settlements and outpost camps, but these were not considered. It is unknown at this point whether or not the increased quotas are sustainable. 

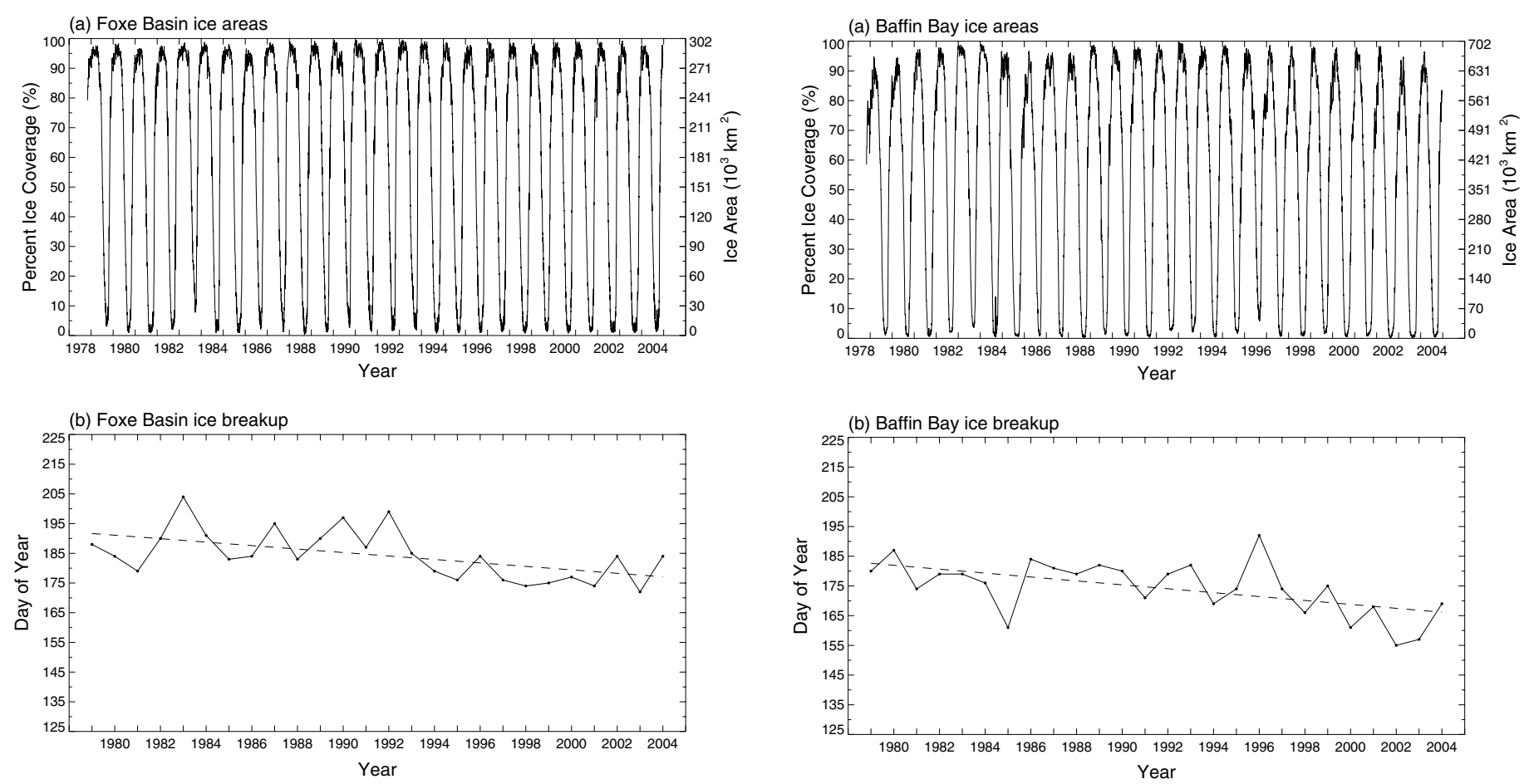

FIG. 5. Foxe Basin: (a) Time series of the daily percent ice coverages and ice areas from 1 November 1978 through 31 December 2004, as determined from the satellite SMMR and SSMI data, and (b) the Julian dates by which the percent ice coverage decreased to $50 \%$ or less, following the winter maximum, for the years 1979-2004 (dashed line indicates the linear least squares fit).

\section{Baffin Bay}

Figure 6a presents percent ice coverages in Baffin Bay from 1 November 1978 through 31 December 2004, as determined from the satellite SMMR and SSMI data. Figure $6 \mathrm{~b}$ presents a plot of the Julian dates by which the percent ice coverage decreased to $50 \%$ or less, following the winter maximum, for the years 1979-2004. As in the cases of Western Hudson Bay and Foxe Basin, there is a clear trend toward earlier ice breakup, this time with a linear least-squares fit rate of $-0.66 \pm 0.20$ days/year, which is statistically significant at a confidence level exceeding $99 \%$ ( $p=0.001)$. This means that ice coverage has been reducing to $50 \%$ of Baffin Bay six to seven days earlier per decade. The latest ice breakup (as determined by reduction to below $50 \%$ ice coverage) came in 1996, and the trend toward earlier ice coverage has been rapid since then, although the overall trend from 1985 to 1996 had been toward later breakup, at a statistically insignificant rate of $0.57 \pm 0.68$ days/year (Fig. 6b).

Most previous analyses of trends in sea ice have not treated Baffin Bay separately, but as part of a continuum extending south through Davis Strait and the Labrador Sea (e.g., Gloersen et al., 1992; Parkinson et al., 1999). Some past reports have indicated a trend toward increasing total amounts of sea ice (Stern and Heide-Jørgensen, 2003) or a fluctuating, perhaps cyclical pattern (Parkinson et al., 1999; Parkinson, 2000a). Heide-Jørgensen and Laidre (2004) reported that between 1979 and 2001, the small

FIG. 6. Baffin Bay: (a) Time series of the daily percent ice coverages and ice areas and (b) Julian dates of first $50 \%$ or less ice cover. Details as in Fig. 5.

areas of open water being used by overwintering marine mammals were becoming smaller in Baffin Bay, unlike Davis Strait or Foxe Basin. Data on sea ice presented by Born (2005) indicated no detectable trend in western Baffin Bay from 1979 to 2004, but a decline in ice cover in eastern Baffin Bay after 2001.

It is difficult to interpret the data from polar bear population studies in relation to local reports of increased numbers of bears seen around settlements and outpost camps. On the basis of a large-scale mark-recapture population study from 1994 to 1997, Taylor et al. (2005) estimated a population of 2100 polar bears in 1997, and calculated a total sustainable harvest of 88 (in which they assumed an annual harvest by Greenland of $18-25$ bears). However, Born (2002) reported an average harvest of $83 \pm$ 13 (SD) from 1993 to 1998 from Qaanaaq and Upernavik alone (Fig. 1), and Born and Sonne (in press) reported that from 1999 to 2003, the harvest for Greenlandic villages in the region averaged 115 bears per year $(\mathrm{SD}=52.9$; range: $68-206$ bears). A conservative estimate of the cumulative total of the polar bear harvest in Baffin Bay, after incorporating the Nunavut increases, is in the vicinity of $150-$ $200+$. Thus, it seems likely that since 1997, the reported annual harvest level has been at least double what was estimated to be sustainable, making it likely that the Baffin Bay polar bear population has been declining since at least that time. In January 2006, the Greenlandic Ministry of Fisheries (Nuuk) announced the establishment of an annual quota of 100 polar bears in West Greenland, most of which will be taken from the Baffin Bay polar bear population by hunters from Qaanaaq, Upernavik, and south of 

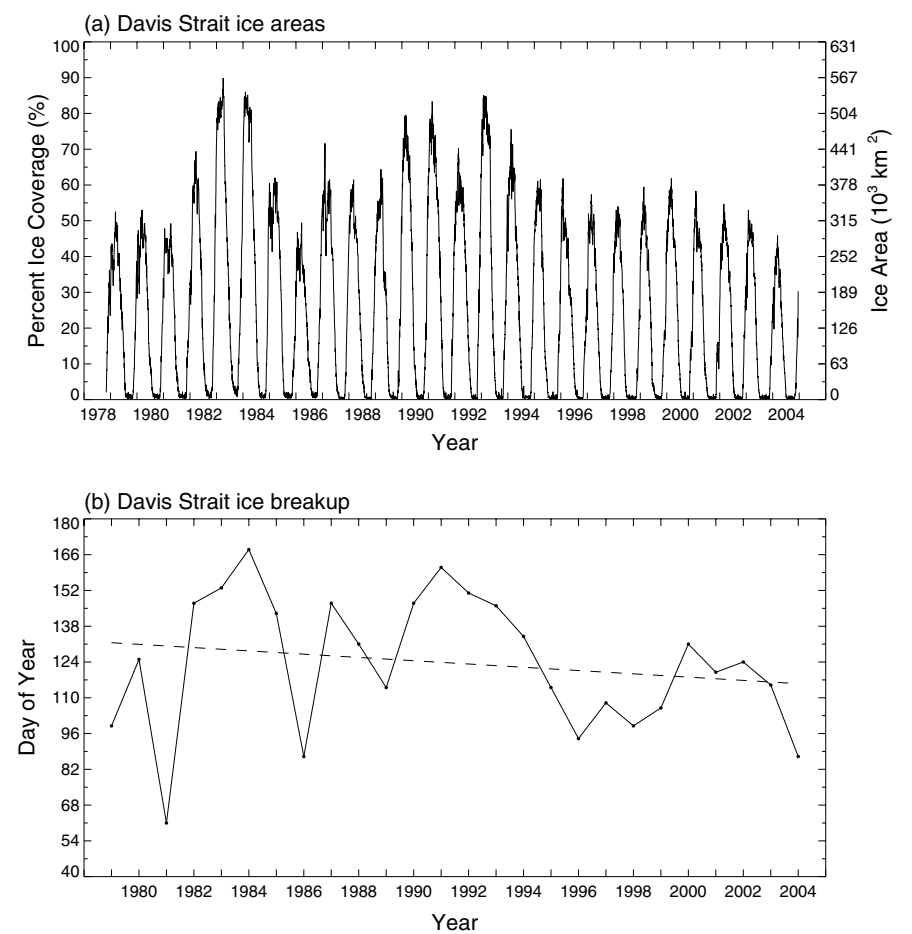

FIG. 7. Davis Strait: (a) Time series of the daily percent ice coverages and ice areas and (b) Julian dates of first $40 \%$ or less ice cover. Details as in Fig. 5.

Upernavik. This means that Greenland hunters are likely to take $80-100$ polar bears per year, which when added to the current quota of 105 for Nunavut results in an annual harvest of approximately 200 bears per year, or at least double the level that was estimated to be sustainable in 1997. The trend toward progressively earlier breakup of the sea ice and increases in numbers of bears seen around settlements along the eastern coast of Baffin Island are similar to those in Western Hudson Bay, though there are no recent data on either the condition of bears on land or the survival of cubs and subadults. However, from the available data on population size in 1997, and harvest statistics from 1993 to 2003, it seems unlikely that more polar bears are being seen near settlements during the open-water period because the population has increased. No data are available on trends in numbers, reproductive rates, or distribution of ringed seals or other potential prey species.

\section{Davis Strait}

Figure 7a presents percent ice coverages in Davis Strait from 1 November 1978 through 31 December 2004, as determined from the satellite SMMR and SSMI data. Figure $7 \mathrm{~b}$ presents a plot of the Julian dates by which the percent ice coverage decreased to $40 \%$ or less, following the winter maximum, for the years 1979-2004. We used $40 \%$ ice cover as the cutoff in Davis Strait, rather than $50 \%$ as in the other regions, because in some years the percent ice coverage in Davis Strait, derived from historical information, never rose above $50 \%$ of the area we delineated. The maximum percent ice coverage in Davis Strait varies considerably more between years than that in Western Hudson Bay, Foxe Basin, or Baffin Bay: it was below 50\% in 1981,1986 , and 2004 , but above $85 \%$ in 1983,1984 , and 1993 (Fig. 7a). Correspondingly large interannual fluctuations are apparent in the timing of ice breakup (Fig. 7b), making a linear trend less meaningful. The long-term slope of the trend line for Davis Strait, $-0.64 \pm 0.69$ days/ year $(p=0.35)$, is not statistically significant; in contrast, the short-term trend, from 1991 to 2004, is decidedly negative (Fig. 7b).

As in Baffin Bay, previous studies of sea ice in Davis Strait have tended to consider the area as part of a single unit extending from Baffin Bay in the north through the Labrador Sea to the south (e.g., Gloersen et al., 1992; Parkinson et al., 1999). Long-term cooling over the whole of Baffin Bay and Davis Strait was reported up to 1990 (Skinner et al., 1998), and Stern and Heide-Jørgensen (2003) reported a trend toward increasing total amounts of sea ice in selected areas of coastal West Greenland. Parkinson et al. (1999) and Parkinson (2000a) reported a fluctuating, perhaps cyclical pattern, with sea ice increases in 1978-83, decreases in 1983-88, increases in 1988-93, and decreases in 1993-99, which are clearly reflected in Figure 7a. In recent years, in some areas within Davis Strait and the Labrador Sea, temperatures have been increasing and the amount of sea ice has been decreasing. In central Davis Strait, Comiso and Parkinson (2004) calculated that the surface warming between the August 1981-July 1992 period and the August 1992-July 2003 period was about $2.6^{\circ} \mathrm{C}$, one of the greatest changes documented in the entire circumpolar Arctic. Similarly, Born (2005) reported significant declines in the total annual ice cover in selected study areas in both the eastern and western portions of Davis Strait. Heide-Jørgensen and Laidre (2004) also examined several relatively small areas known to have open water in March and found that between 1979 and 2001, there was a trend toward enlargement of those areas.

The present status and trend of the polar bear population of Davis Strait, which is shared by Nunavut, Labrador, Quebec, and West Greenland, are unknown. On the basis of a mark-recapture population study conducted on the coastal sea ice in spring from 1976 to 1979 , Stirling et al. (1980) estimated the total population in the vicinity of southeastern Baffin Island at 700-900. That estimate was probably biased low because it was done in spring, when an unknown number of bears would have been much farther offshore on the pack ice and therefore inaccessible for capture. In a subsequent study limited to the Labrador coast, from 1991 through 1994, no attempt was made to estimate population size, but the number of bears captured per hour of helicopter search in those years was approximately double what it had been during previous studies from 1975 to 1979 (Stirling and Kiliaan, 1980; I. Stirling, unpubl. data). Large adult males were abundant, which, subjectively at least, is also a fairly reliable indicator that the population was not being overharvested. For example, when the polar bear population in the Southern Beaufort Sea was being overharvested in the late 1960s and early 
1970s, bears older than 10 years were almost nonexistent there, but they became abundant as the population recovered (Stirling, 2002).

Between the time of the first polar bear studies in Davis Strait and the Labrador coast in the 1970s and that of the later, more limited studies in northern Labrador in the 1990s, the abundance of harp seals and hooded seals increased significantly (Bowen et al., 1987; Stenson et al., 1997; Healey and Stenson, 2000; Anonymous, 2005). This is particularly relevant to the likely increase in the size of the polar bear population between the late 1970s and early 1990s because both these seal species pup in large numbers near the outer edge of the pack ice in March (Fig. 1), and are much less wary than other seal species of being approached to close distances by humans or polar bears (I. Stirling, unpubl. observations). Furthermore, both harp and hooded seals are much larger than ringed seals, so each animal killed, on average, makes much more fat available to a bear. Fat is the most favored part of a seal to a polar bear (Stirling and McEwan, 1975) and is digested with a digestive efficiency of $98 \%$ (Best, 1975), after which it can be stored on the body of the bear for use up to several months later, when food may not be available (Nelson et al., 1983). Outside the pupping and breeding season, harp seals also haul out on the ice in groups of various sizes, and humans can often approach closely enough to capture them with a hand-thrown net for tagging. Similarly, periodic onshore winds along the northern Labrador coast during winter and spring sometimes compress the ice sufficiently in some areas to cause harp seals to be temporarily stranded on the sea ice, with limited access to water for escape from predators. Lastly, the harp seal population increased from less than two million in the early 1970s to over five million by 2000 (Anonymous, 2005). Taken together, the larger size, reduced wariness, and large numbers of accessible individual seals have meant that polar bears in the Davis Strait population have had a very large, accessible food base for two to three decades that other populations of polar bears have not had. This is particularly relevant because, from analysis of fatty acids from polar bears from Davis Strait, Iverson et al. (2006) demonstrated that harp seals are by far the most important species in the diet of polar bears in that area, in contrast to the predominance of ringed seals in most other areas (Stirling and Archibald, 1977; Smith, 1980; Stirling and Øritsland, 1995). Throughout Davis Strait, harp seals comprised $50 \%$ of the bears' diets, which is consistent with the large increase in the harp seal population in this region. Off southern Labrador closer to the whelping patch (Fig. 1), harp seals accounted for $90 \%$ of diets. The highest proportion of hooded seals in polar bear diets was recorded in animals from northern Davis Strait, closest to the seals' northern whelping patch (Sergeant, 1974; Bowen et al., 1987; Stirling and Holst, 2000) (Fig. 1).

In recent years, Inuit hunters in Nunavut have reported seeing many more bears around the coast of SE Baffin Island. Those observations were interpreted as evidence of an increase in polar bear population size, and consequently the Nunavut quota was increased by 12 (35\%), from 34 to 46 (Table 1). From the limited information available, it seems likely that the Davis Strait population of polar bears increased to an unknown number between the late 1970s and at least the early 1990s, possibly in response to a greatly increased food supply and an increased amount of sea-ice habitat through the 1980s (Fig. 7b). However, the harp seal population stabilized in the early 1990 s, and between 1993 and 2002, there was a significant reduction in ice cover and a rapid reduction of sea ice in spring. Such conditions have previously been correlated with increased mortality of pups (Sergeant, 1991; Johnson et al., 2005) and generally support the hypothesis that juvenile mortality in some recent years has been up to five times greater (Anonymous, 2003). While the present population size and trend of the Davis Strait polar bear population are unknown, it seems likely that the population is no longer increasing and could, in time, be negatively affected by the trends toward less sea ice, earlier breakup, and possibly a decline in the total population of harp seals if the climate continues to warm as is predicted.

\section{Hudson Strait}

Although Hudson Strait was not considered directly in this study, Heide-Jørgensen and Laidre (2004) examined several relatively small areas known to have open water in March, as part of an assessment of the importance of polynya areas to wintering marine mammals in Baffin Bay and adjacent areas. They found that between 1979 and 2001, there was a steady trend toward enlargement of the open-water areas, which is consistent with the trends noted above for the adjacent regions. Their observations are generally consistent with other studies that have shown increasing length of the ice-free period in Hudson Strait and later freeze-up in northeastern Hudson Bay (Houser and Gough, 2003; Gagnon and Gough, 2005).

\section{Eastern Hudson Bay}

Figure 8a presents percent ice coverages in Eastern Hudson Bay from 1 November 1978 through 31 December 2004, as determined from the satellite SMMR and SSMI data. Figure $8 \mathrm{~b}$ presents a plot of the Julian dates by which the percent ice coverage decreased to $50 \%$ or less, following the winter maximum, for the years 1979-2004. As in Western Hudson Bay (Fig. 2), percent ice coverage consistently rose above $90 \%$ in winter, and reduction to $50 \%$ ice cover consistently occurred between Julian day 140 and day 195. In both portions of the Bay, the latest breakup occurred in 1992. In Western Hudson Bay, the earliest breakup came in 2003 (Fig. 2b), whereas in Eastern Hudson Bay the earliest breakup came in 2001, and $2003 \mathrm{had}$ a considerably later breakup, at least as indicated by the $50 \%$ ice cutoff date (Fig. 8b). Taken as a whole, the trend toward earlier breakup in Eastern Hudson Bay is weaker, 

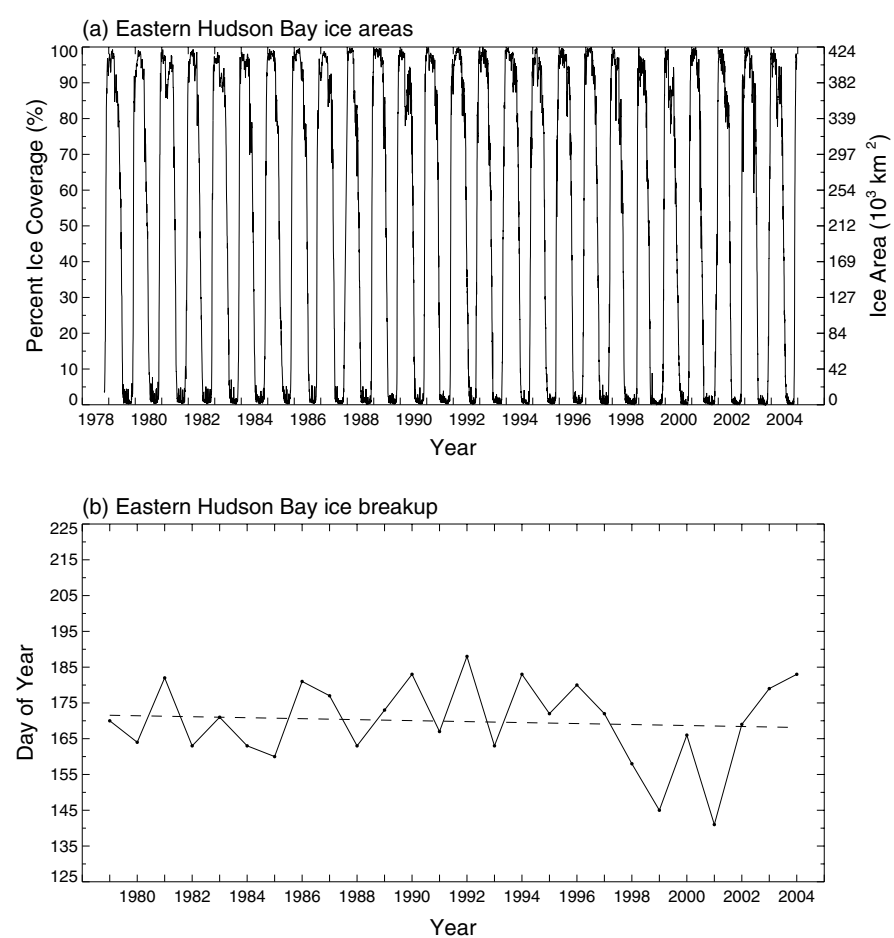

FIG. 8. Eastern Hudson Bay: (a) Time series of the daily percent ice coverages and ice areas and (b) Julian dates of first $50 \%$ or less ice cover. Details as in Fig. 5.

especially with the later breakups in 2002-04 and the seemingly random fluctuations in earlier years (Fig. 8b). The trend value, at $-0.14 \pm 0.31$ days/year, was not statistically significant ( $p=0.65)$, had the lowest magnitude of any of the regions, and was less than $20 \%$ of the magnitude of the -0.75 days/year slope for Western Hudson Bay. Other studies that considered smaller components of Eastern Hudson Bay (i.e., the southern coast of Hudson Bay and James Bay) independently reported statistically insignificant (Stirling et al., 2004) and significant (Gagnon and Gough, 2005) trends toward earlier breakup for these two areas.

We included Eastern Hudson Bay in this study because the polar bears there, as in the four other regions discussed above, spend several months fasting on land during the open-water season, in this case along the Ontario coast and on some of the small, uninhabited islands in James Bay. In the mid-1990s, bears of each age and sex class in Eastern Hudson Bay were in significantly better condition than their counterparts in Western Hudson Bay during the open-water season, probably because the ice breaks up later there, so they consistently had a longer time to feed before beginning their fast (Stirling et al., 1999). However, recent studies have confirmed a statistically significant trend toward progressively earlier breakup along the south coast of Hudson Bay (Gough et al., 2004a; Gagnon and Gough, 2005), so that the duration of the open-water season adjacent to the shore is increasing. In a pattern similar to that already demonstrated in Western Hudson Bay, the condition of polar bears in Eastern Hudson Bay now also appears to have declined between 1984-86 and
2000-04 (M. Obbard and M. Cattet, unpubl. data, cited in Richardson et al., in press). Although these trends in bear condition and ice breakup were initially more difficult to detect in Eastern Hudson Bay than in Western Hudson Bay, as explained above, we predict that if the climate continues to warm in that area, they will continue as presently projected.

Details of the present status and trend of the polar bear population in Eastern Hudson Bay are unknown. Despite the ecological similarities between Eastern Hudson Bay and the other polar bear populations discussed above, there have not yet been reports of an increase in the number of sightings of polar bears in Eastern Hudson Bay that might lead to suggestions of population increase. However, it is possible this contrast may be explained by the distribution of Inuit settlements in the area in relation to where the bears fast during the open-water season. The only Nunavut Inuit village in Eastern Hudson Bay from which polar bears are hunted is Sanikiluaq in the Belcher Islands (Fig. 1). However, the first ice to break up in Eastern Hudson Bay does so along the eastern coast of Hudson Bay and the last does so along the Ontario coast (Gagnon and Gough, 2005), with the result that polar bears rarely summer on land along the coast of either Quebec or the Belcher Islands. Consequently, no conflicts with humans are reported from either area during the open-water season. Instead, the polar bears remain on the ice until it finally breaks up along the Ontario coast, after which the bears finally go ashore there to fast until freeze-up in the fall (Prevett and Kolenosky, 1982; Stirling et al., 2004). Unlike the settlements in Nunavut, which are distributed along the coast, Indian settlements along the Ontario coast tend to be several kilometres inland, so that although people travelling on the coast see polar bears, there are few camps and no villages to attract hungry bears. The apparent result is fewer reports of human-bear conflicts.

\section{SUMMARY}

There are five polar bear populations in the Canadian Arctic (including two shared with Greenland) in which the whole population must fast on shore for several months because all the sea ice in the area melts completely. In four of these populations (Western Hudson Bay, Foxe Basin, Baffin Bay, and Davis Strait), residents of coastal settlements have reported seeing more polar bears and having more problem bear encounters during the open-water season, particularly in the fall. In those areas, the increased numbers of sightings have been interpreted as indicative of an increase in population size, with the result that quotas for Inuit hunters were increased. However, in Western Hudson Bay, the decline in population size, condition, and survival of young as a consequence of earlier breakup of the sea ice brought about by climate warming have all been well documented (Stirling et al., 1999; Gagnon and Gough, 2005; Regehr et al., 2005; I. Stirling and N.J. Lunn, unpub. 
data). In Baffin Bay, the available data suggest that the population is being overharvested, so the reason for seeing more polar bears is unlikely to be an increase in population size. We suggest that the increase in numbers of sightings of polar bears in Foxe Basin and Davis Strait may also be influenced by factors related to earlier breakup of the sea ice. In Davis Strait and Western Hudson Bay, preliminary information suggests that populations of seals preyed upon by polar bears may also be affected by changes in the sea ice due to climate warming. We hypothesize that, if the climate continues to warm as projected by the IPCC, then polar bears in all five populations discussed in this paper will be stressed and are likely to decline in numbers, probably significantly so. As these populations decline, there will likely also be continuing, possibly increasing, numbers of problem interactions between bears and humans as the bears seek alternative food sources. Taken together, the data and concepts reported in this paper suggest that a precautionary approach be taken to the harvesting of polar bears and that the potential effects of climate warming be incorporated into planning for the management and conservation of this species throughout the Arctic.

\section{ACKNOWLEDGEMENTS}

This study was supported for Ian Stirling by the Canadian Wildlife Service, the Department of Biological Sciences at the University of Alberta, the Natural Sciences and Engineering Research Council of Canada, the Nunavut Wildlife Management Board, the Polar Continental Shelf Project, and the World Wildlife Fund (Canada and International) and for Claire Parkinson by NASA's Cryospheric Sciences Program. We thank N.J. Lunn and E. Richardson for significant help with data extraction and creation of the polar bear figures. We also thank Nick DiGirolamo of Science Systems and Applications, Inc. (SSAI) and NASA Goddard Space Flight Center, for excellent assistance with the sea-ice calculations and the five sea-ice figures.

\section{REFERENCES}

AARS, J., DEROCHER, A., and LUNN, N.J., eds. In press. Polar bears. Proceedings of the 14th Working Meeting of the IUCN/ SSC Polar Bear Specialist Group, 20-24 June 2005, Seattle, Washington. Occasional Paper of the IUCN Species Survival Commission. Gland, Switzerland: International Union for Conservation of Nature and Natural Resources.

ANONYMOUS. 2003. Atlantic seal hunt 2003-2005 management plan. Fisheries Resource Management - Atlantic. Fisheries and Oceans Canada. p. A10.

. 2005. Report of the International Council for the Exploration of the Sea (ICES)/Northwest Atlantic Fisheries Organization (NAFO) Working Group on harp and hooded seals (WGHARP). 30 August -3 September 2005, St. John's, Newfoundland. ICES WGHARP Report 2005. ICES Advisory Committee on Fishery Management. ICES C.M. 2006/ACFM:06.
ATKINSON, S.N., and RAMSAY, M.A. 1995. The effects of prolonged fasting on the body composition and reproductive success of female polar bears. Functional Ecology 9:559-567.

BEST, R.C. 1975. Ecological aspects of polar bear nutrition. In: Phillips, R.L., and Jonkel, C.J., eds. Proceedings of the 1975 Predator Symposium. Missoula: Montana Forest and Conservation Experiment Station, University of Montana. 203-211.

BJØRGO, E., JOHANSESSEN, O.M., and MILES, M.W. 1997. Analysis of merged SMMR-SSMI time series of Arctic and Antarctic sea ice parameters 1978-1995. Geophysical Research Letters 24:413-416.

BORN, E.W. 2002. Research on polar bears in Greenland. In: Lunn, N.J., Schliebe, S., and Born, E.W., eds. 2002. Polar bears. Proceedings of the 13th Working Meeting of the IUCN/SSC Polar Bear Specialist Group. Occasional Paper of the IUCN Species Survival Commission No. 26. Gland, Switzerland: International Union for Conservation of Nature and Natural Resources. 67-74.

. 2005. An assessment of the effects of hunting and climate on walruses in Greenland. PhD Thesis. Natural History Museum, University of Oslo. $356 \mathrm{p}$.

BORN, E.W., and SONNE, C. In press. Report on polar bears in Greenland, 2001 to 2005. In: Aars, J., Derocher, A.E., and Lunn, N.J., eds. Proceedings of the 14th Working Meeting of the IUCN/SSC Polar Bear Specialist Group, 20-24 June 2005, Seattle, Washington. Occasional Paper of the IUCN Species Survival Commission. Gland, Switzerland: International Union for Conservation of Nature and Natural Resources.

BOWEN, W.D., MYERS, R.A., and HAY, K. 1987. Abundance estimation of a dispersed, dynamic population: Hooded seals (Cystophora cristata) in the Northwest Atlantic. Canadian Journal of Fisheries and Aquatic Sciences 44:282-295.

CAVALIERI, D.J., PARKINSON, C.L., GLOERSEN, P., COMISO, J.C., and ZWALLY, H.J. 1999. Deriving long-term time series of sea ice cover from satellite passive-microwave multisensor data sets. Journal of Geophysical Research 104 (C7):15803-15814.

COMISO, J.C., and PARKINSON, C.L. 2004. Satellite-observed changes in the Arctic. Physics Today 57(8):38-44.

DEROCHER, A.E., and STIRLING, I. 1992. The population dynamics of polar bears in western Hudson Bay. In: McCullough, D.R., and Barrett, R.H., eds. Wildlife 2001: Populations. London: Elsevier Applied Science. 1150-1159.

1996. Aspects of survival in juvenile bears. Canadian Journal of Zoology 74:1246-1252.

DEROCHER, A.E., STIRLING, I., and ANDRIASHEK, D. 1992. Pregnancy rates and serum progesterone levels of polar bears in western Hudson Bay. Canadian Journal of Zoology 70: $561-566$.

DEROCHER, A.E., GARNER, G.W., LUNN, N.J., and WIIG, Ø., eds. 1998. Proceedings of the 12th Working Meeting of the IUCN/SSC Polar Bear Specialist Group. Occasional Paper of the IUCN Species Survival Commission No. 19. Gland, Switzerland: International Union for Conservation of Nature and Natural Resources. 159 p. 
DEROCHER, A.E., LUNN, N.J., and STIRLING, I. 2004. Polar bears in a warming climate. Integrative and Comparative Biology 44:163-176.

ETKIN, D.A. 1991. Break-up in Hudson Bay: Its sensitivity to air temperatures and implications for climate warming. Climatological Bulletin 25:21-34.

FERGUSON, S.H., STIRLING, I., and McLOUGHLIN, P. 2005. Climate change and ringed seal (Phoca hispida) recruitment in western Hudson Bay. Marine Mammal Science 21:121-135.

GAGNON, A.S., and GOUGH, W.A. 2005. Trends in the dates of ice freeze-up and breakup over Hudson Bay, Canada. Arctic 58(4):370-382.

GASTON, A.J., WOO, K., and HIPFNER, J.M. 2003. Trends in forage fish populations in northern Hudson Bay since 1981, as determined from the diet of nestling thick-billed murres Uria lomvia. Arctic 56(3):227-233.

GLOERSEN, P., CAMPBELL, W.J., CAVALIERI, D.J., COMISO, J.C., PARKINSON, C.L., and ZWALLY, H.J. 1992. Arctic and Antarctic sea ice, 1978-1987: Satellite passive-microwave observations and analysis. Washington, D.C.: National Aeronautics and Space Administration. 290 p.

GOUGH, W.A., CORNWELL, A.R., and TSUJI, L.J.S. 2004a. Trends in seasonal sea ice duration in southwestern Hudson Bay. Arctic 57(3):299-305.

GOUGH, W.A., GAGNON, A.S., and LAU, H.P. 2004b. Interannual variability of Hudson Bay ice thickness. Polar Geography 28: $222-238$.

GNWT (GOVERNMENT OF THE NORTHWEST TERRITORIES). 2005. Policy 52.06: Traditional knowledge. http://www.enr.gov.nt.ca/plc/policy.htm.

HEALEY, B.P., and STENSON, G.B. 2000. Estimating pup production and population size of the northwest Atlantic harp seal (Phoca groenlandicus). Canadian Stock Assessment Secretariat Research Document 2000/081. Ottawa: Canadian Science Advisory Secretariat, Fisheries and Oceans Canada. $27 \mathrm{p}$.

HEIDE-JØRGENSEN, M.P., and LAIDRE, K.L. 2004. Declining extent of open-water refugia for top predators in Baffin Bay and adjacent waters. Ambio 33:488-495.

HOUSER, C., and GOUGH, W.A. 2003. Variations in sea ice in the Hudson Strait: 1971 - 1999. Polar Geography 26:11-24.

IVERSON, S.J., STIRLING, I., and LAND, S.L.C. 2006. Spatial, temporal, and individual variation in the diets of polar bears across the Canadian Arctic: Links with and indicators of changes in prey populations. In: Boyd, I., ed. Management of marine ecosystems: Monitoring change in upper trophic levels. Symposium of the Zoological Society of London. 98-117.

JOHANNESSEN, O.M., MILES, M., and BJØRGO, E. 1995. The Arctic's shrinking sea ice. Nature 376:126-127.

JOHANNESSEN, O.M., BENGTSSON, L., MILES, W.M., KUZMINA, S.I., SEMENOV, V.A., ALEKSEEV, G.V., NAGURNYI, A.P., ZAKHAROV, V.F., BOBYLEV, L.P., PETTERSSON, L.H., HASSELMANN, K., and CATTLE, H.P. 2004. Arctic climate change: Observed and modelled temperature and sea-ice variability. Tellus 56A(4):328-341.

JOHNSON, D.W., FRIEDLAENDER, A.S., TORRES, L.G., and LAVIGNE, D.M. 2005. Variation in sea ice cover on the east coast of Canada from 1969 to 2002: Climate variability and implications for harp and hooded seals. Climate Research 29: 209-222.

KELLY, B.P. 2001. Climate change and ice breeding pinnipeds. In: Walther, G.-R., Burga, C.A., and Edwards, P.J., eds. "Fingerprints" of climate change: Adapted behaviour and shifting species' ranges. New York: Kluwer Academic/Plenum Publishers. 43-55.

LUNN, N.J., STIRLING, I., and NOWICKI, S.N. 1997. The distribution and abundance of seals in western Hudson Bay. Canadian Journal of Fisheries and Aquatic Sciences 54: 914-921.

LUNN, N.J., TAYLOR, M., CALVERT, W., STIRLING, I., OBBARD, M., ELLIOTT, C., LAMONTAGNE, G., SCHAEFFER, J., ATKINSON, S., CLARK, D., BOWDEN, E., and DOIDGE, B. 1998. Polar bear management in Canada 1993 - 1996. In: Derocher, A.E., Garner, G.W., Lunn, N.J., and Wiig, Ø., eds. Proceedings of the 12th Working Meeting of the IUCN/SSC Polar Bear Specialist Group. Occasional Paper of the IUCN Species Survival Commission No. 19. Gland, Switzerland: International Union for Conservation of Nature and Natural Resources. 51-68.

LUNN, N.J., SCHLIEBE, S., and BORN, E.W., eds. 2002a. Polar bears. Proceedings of the 13th Working Meeting of the IUCN/ SSC Polar Bear Specialist Group. Occasional Paper of the IUCN Species Survival Commission No. 26. Gland, Switzerland: International Union for Conservation of Nature and Natural Resources. $155 \mathrm{p}$.

LUNN, N.J., ATKINSON, S., BRANIGAN, M., CALVERT, W., CLARK, D., DOIDGE, B., ELLIOTT, C., NAGY, J., OBBARD, M., OTTO, R., STIRLING, I., TAYLOR, M., VANDAL, D., and WHEATLEY, M. 2002b. Polar bear management in Canada 1987-2000. In: Lunn, N.J., Schliebe, S., and Born, E.W., eds. Polar bears. Proceedings of the 13th Working Meeting of the IUCN/SSC Polar Bear Specialist Group. Occasional Paper of the IUCN Species Survival Commission No. 26. Gland, Switzerland: International Union for Conservation of Nature and Natural Resources. 41-52.

LUNN, N.J., BRANIGAN, M., CARPENTER, L., CHAULK, K., DOIDGE, B., GALIPEAU, J., HEDMAN, D., HUOT, M., MARAJ, R., OBBARD, M., OTTO, R., STIRLING, I., TAYLOR, M., and WOODLEY, S. In press. Polar bear management in Canada 2001-2004. In: Aars, J., Derocher, A., and Lunn, N.J., eds. Polar bears. Proceedings of the 14th Working Meeting of the IUCN/SSC Polar Bear Specialist Group, 20-24 June 2005, Seattle, Washington. Occasional Paper of the IUCN Species Survival Commission. Gland, Switzerland: International Union for Conservation of Nature and Natural Resources.

MASLANIK, J.A., SERREZE, M.C., and BARRY, R.G. 1996. Recent decreases in Arctic summer ice cover and linkages to atmospheric circulation anomalies. Geophysical Research Letters 23(13):1677-1680.

NAKASHIMA, D.J. 1993. Astute observers on the sea ice edge: Inuit knowledge as a basis for Arctic co-management. In: Inglis, J.T., ed. Traditional ecological knowledge: Concepts and cases. Ottawa: Canadian Museum of Nature and International Development Research Centre. 99-110. 
NELSON, R.A., FOLK, G.E., Jr., PFEIFFER, E.W., CRAIGHEAD, J.J., JONKEL, C.J., and STEIGER, D.L. 1983. Behavior, biochemistry, and hibernation in black, grizzly, and polar bears. International Conference on Bear Research and Management 5:284-290.

PAETKAU, D., AMSTRUP, S.C., BORN, E.W., CALVERT, W., DEROCHER, A.E., GARNER, G.W., MESSIER, F., STIRLING, I., TAYLOR, M., WIIG, Ø., and STROBECK, C. 1999. Genetic structure of the world's polar bear populations. Molecular Ecology 8:1571-1585.

PARKINSON, C.L. 1992. Spatial patterns of increases and decreases in the length of the sea ice season in the north polar region, 1979-1986. Journal of Geophysical Research 97(C9): $14377-14388$.

- 2000a. Recent trend reversals in Arctic sea ice extents: Possible connections to the North Atlantic Oscillation. Polar Geography 24(1):1-12.

-2000b. Variability of Arctic sea ice: The view from space, an 18-year record. Arctic 53(4):341-358.

PARKINSON, C.L., and CAVALIERI, D.J. 1989. Arctic sea ice 1973-1987: Seasonal, regional, and interannual variability. Journal of Geophysical Research 94(C10):14499-14523.

PARKINSON, C.L., CAVALIERI, D.J., GLOERSEN, P., ZWALLY, H.J., and COMISO, J.C. 1999. Arctic sea ice extents, areas, and trends, 1978-1996. Journal of Geophysical Research 104(C9):20837-20856.

PRESTRUD, P., and STIRLING, I. 1994. The International Polar Bear Agreement and the current status of polar bear conservation. Aquatic Mammals 20:1-12.

PREVETT, P., and KOLENOSKY, G.B. 1982. The status of polar bears in Ontario. Le Naturaliste Canadien (Revue d'Écologie et de Systématique) 109:933-939.

REGEHR, E., LUNN, N.J., AMSTRUP, S.C., and STIRLING, I. 2005. Population decline of polar bears in Western Hudson Bay in relation to climatic warming. 16th Biennial Conference on the Biology of Marine Mammals. 12-16 December 2005, San Diego, California: Society for Marine Mammalogy. 233 (Abstract only).

RAMSAY, M.A., and STIRLING, I. 1988. Reproductive biology and ecology of female polar bears (Ursus maritimus). Journal of Zoology (London) Series A 214:601-634.

RICHARDSON, E., BRANIGAN, M., CALVERT, W., CATTET, M., DEROCHER, A.E., DOIDGE, W., HEDMAN, D., LUNN, N.J., McLOUGHLIN, P., OBBARD, M.E., STIRLING, I., and TAYLOR, M. In press. Research on polar bears in Canada 2001-2004. In: Aars, J., Derocher, A.E., and Lunn, N.J., eds. Proceedings of the 14th Working Meeting of the IUCN/SSC Polar Bear Specialist Group, 20-24 June 2005, Seattle, Washington. Gland, Switzerland: International Union for Conservation of Nature and Natural Resources.

ROTHROCK, D.A., YU, Y., and MAYKUT, G.A. 1999. Thinning of the Arctic sea-ice cover. Geophysical Research Letters 26:3469-3472.

SERGEANT, D.E. 1974. A re-discovered whelping population of hooded seals Cystophora cristata Erxleben and its possible relationship to other populations. Polarforschung 44:1-7.
1991. Harp seals, man, and ice. Canadian Journal of Fisheries and Aquatic Sciences Special Publication 114. 153 p. SKINNER, W.R., JEFFERIES, R.L., CARLETON, T.J., ROCKWELL, R.F., and ABRAHAM, K.F. 1998. Prediction of reproductive success and failure in lesser snow geese based on early season climatic variables. Global Change Biology 4:3-16.

SMITH, T.G. 1980. Polar bear predation of ringed and bearded seals in the land-fast sea ice habitat. Canadian Journal of Zoology 58:2201-2209.

SODEN, B.J., WETHERALD, R.T., STENCHIKOV, G.L., and ROBOCK, A. 2002. Global cooling after the eruption of Mount Pinatubo: A test of climate feedback by water vapor. Science 296:727.

STENSON, G.B., MYERS, R.A., NI, I.-H., and WARREN, W.G. 1997. Pup production and population growth of hooded seals (Cystophora cristata) near Newfoundland, Canada. Canadian Journal of Fisheries and Aquatic Sciences 54:209-216.

STERN, H.L., and HEIDE-JØRGENSEN, M.P. 2003. Trends and variability of sea ice in Baffin Bay and Davis Strait. Polar Research 22:11-18.

STIRLING, I. 1988. Polar bears. Ann Arbor, Michigan: University of Michigan Press. 232 p.

- 2002. Polar bears and seals in the eastern Beaufort Sea and Amundsen Gulf: A synthesis of population trends and ecological relationships over three decades. Arctic 55(Supp. 1):59-76.

- 2005. Reproductive rates of ringed seals and survival of pups in northwestern Hudson Bay, Canada, 1991-2000. Polar Biology 28:381-387.

STIRLING, I., and ARCHIBALD, W.R. 1977. Aspects of predation of seals by polar bears in the eastern Beaufort Sea. Journal of the Fisheries Research Board of Canada 34:1126-1129.

STIRLING, I., and DEROCHER, A.E. 1993. Possible impacts of climatic warming on polar bears. Arctic 46(3):240-245.

STIRLING, I., and HOLST, M. 2000. Observations of hooded seals (Cystophora cristata) in the northwestern Labrador Sea and southern Davis Strait in March-April, 1998. Canadian FieldNaturalist 114:147-149.

STIRLING, I., and KILIAAN, H.P.L. 1980. Population ecology studies of the polar bear in northern Labrador. Canadian Wildlife Service Occasional Paper 42. 19 p.

STIRLING, I., and McEWAN, E.H. 1975. Caloric value of whole ringed seals (Phoca hispida) in relation to polar bear (Ursus maritimus) ecology and hunting behavior. Canadian Journal of Zoology 53:1021-1026.

STIRLING, I., and ØRITSLAND, N.A. 1995. Relationships between estimates of ringed seal and polar bear populations in the Canadian Arctic. Canadian Journal of Fisheries and Aquatic Sciences 52:2594-2612.

STIRLING, I., and SMITH, T.G. 2004. Implications of warm temperatures and an unusual rain event for the survival of ringed seals on the coast of southeastern Baffin Island. Arctic 57(1): 59-67.

STIRLING, I., CALVERT, W., and ANDRIASHEK, D. 1980. Population ecology studies of the polar bear in the area of southeastern Baffin Island. Canadian Wildlife Service Occasional Paper 44. 31 p. 
STIRLING, I., SPENCER, C., and ANDRIASHEK, D. 1989. Immobilization of polar bears (Ursus maritimus) with Telazol in the Canadian Arctic. Journal of Wildlife Disease 25:159-168. STIRLING, I., LUNN, N.J., and IACOZZA, J. 1999. Long-term trends in the population ecology of polar bears in western Hudson Bay in relation to climatic change. Arctic 52(3): 294-306.

STIRLING, I., LUNN, N.J., IACOZZA, J., ELLIOTT, C., and OBBARD, M. 2004. Polar bear distribution and abundance on the southwestern Hudson Bay coast during open water season, in relation to population trends and annual ice patterns. Arctic 57(1):15-26.
TAYLOR, M.K., AKEEAGOK, S., ANDRIASHEK, D., BARBOUR, W., BORN, E.W., CALVERT, W., CLUFF, H.D., FERGUSON, S., LAAKE, J., ROSING-ASVID, A., STIRLING, I., and MESSIER, F. 2001. Delineation of Canadian and Greenland polar bear (Ursus maritimus) populations using cluster analysis of movements. Canadian Journal of Zoology 79: 690-709.

TAYLOR, M.K., LAAKE, J., McLOUGHLIN, P.D., BORN, E.W., CLUFF, H.D., FERGUSON, S.H., ROSING-ASVID, A., SCHWEINSBURG, R., and MESSIER, F. 2005. Demography and viability of a hunted population of polar bears. Arctic 58(2):203-214. 